\title{
Disegnare la memoria. I primi rilievi archeologici ottocenteschi in Basilicata
}

Giuseppe Damone

Abstract

Una nuova sensibilità verso le rovine archeologiche, soprattutto all'indomani della scoperta delle città di Pompei ed Ercolano distrutte dall'eruzione del Vesuvio nel 79 d. C., porta alla produzione, a partire dal XVIII secolo, di numerosi scritti e disegni che mettono le stesse al centro del dibattito scientifico. Si colloca in questo contesto la prima documentazione del patrimonio archeologico lucano durante il XIX secolo. Ė quanto emerge da una sistematica disamina del materiale conservato presso l'Archivio di Stato di Potenza dove è stato possibile rintracciare i primi disegni di rilievo allegati ad alcune perizie redatte per lavori di scavo e restauro del santuario extraurbano di Hera, a Metaponto, anche noto con il nome di Tavole Palatine. Altra traccia importante di documentazione grafica del patrimonio architettonico-archeologico è spesso contenuta nella letteratura ottocentesca, periodo in cui i primi studiosi di antichità organizzano campagne di scavo e di studio di ruderi rimasti sino a quel momento ai margini del dibattito accademico e condannati, per molti secoli, alla lenta rovina. Seppur esigui, questi documenti denotano una prima sensibilità per la rappresentazione grafica nel più ampio ambito della documentazione del patrimonio archeologico lucano, spesso affidata ai soli testi scritti.

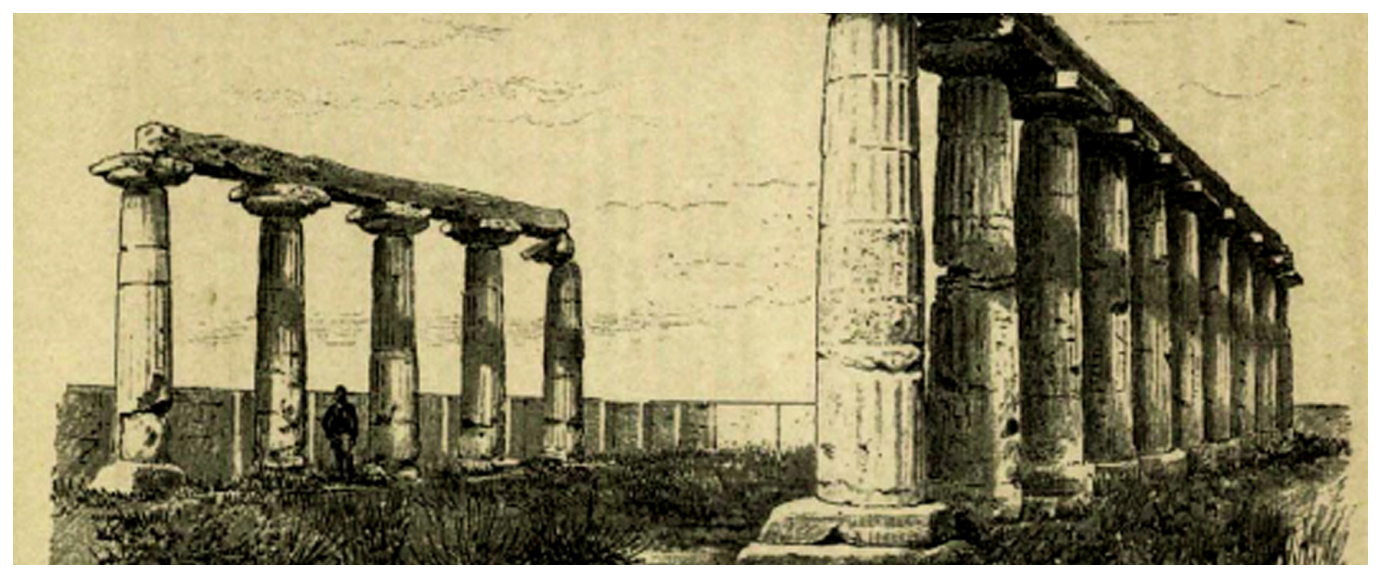




\section{Introduzione}

Lo studio di architetture o di complessi architettonici storici ha un ruolo centrale per la conoscenza di quanto ereditato dal passato, oltre a rappresentare un tassello importante per 'traghettare' queste testimonianze verso il futuro. Documentare con rilievi a diversa scala di rappresentazione queste realtà significa garantirne la memoria.

La documentazione del patrimonio culturale rappresenta, altresì, un particolare campo "entro il quale si integrano le varie forme di espressione grafica" [Cundari et al. 20 I2]. Ma l'esigenza di documentare architetture e ruderi non è una questione solo attuale, ma affonda le sue origini nella 'storia della conoscenza' dell'uomo e, dunque, nell'esigenza avvertita da quest'ultimo di rappresentare quanto lo circonda. Disegnare significa essere capaci di raccontare, facendo diventare così il disegno un importante strumento di comunicazione per molti aspetti insostituibile.

Nel corso dei secoli poi si sono teorizzate e affinate tecniche per il disegno, ma tutte partono da uno stesso caposaldo: la capacità di saper osservare. Non esiste, infatti, disegno di un oggetto, sia esso manufatto architettonico, porzione di città o di paesaggio, senza una preliminare e attenta fase di osservazione.

'Il disegno, tuttavia, è anche uno strumento di rappresentazione universale, estremamente rapido, per descrivere, visualizzare e comunicare" [Guidano I99 I], divenendo spesso più immediato e comprensibile di un testo scritto, riuscendo per esempio a prefigurare un edificio o una porzione di spazio architettonico più velocemente di una descrizione verbale o scritta. È attraverso il disegno di rilievo che realtà costruite o porzioni di paesaggio sono restituiti sul foglio da disegno. Nel rilievo è possibile riconoscere l'operazione necessaria per la conoscenza di un oggetto attraverso la raccolta di dati poi restituiti con il disegno grafico, ma anche il processo mediante il quale le informazioni sono ordinate secondo la 'consapevolezza' e, quindi, l'interpretazione del rilevatore che, così facendo, restituisce una documentazione rielaborata in maniera critica.

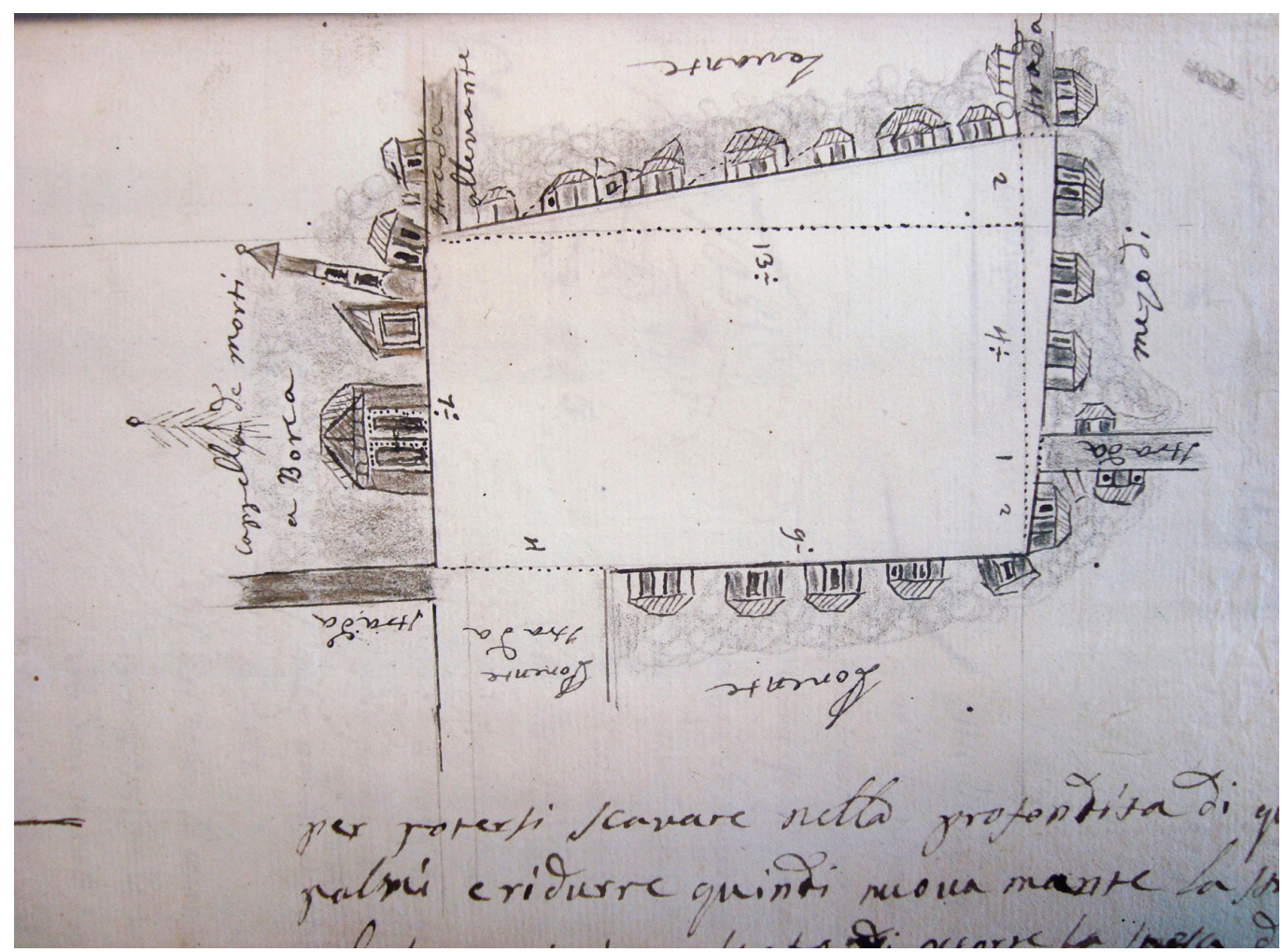


Fig. 2.Vedute delle rovine

del tempio di Hera a

Metaponto realizzate da

Louis-Jean Desprez (in

alto) e da Claude-Louis

Chậtelet (in basso), pub-

blicate nell'opera Voyage
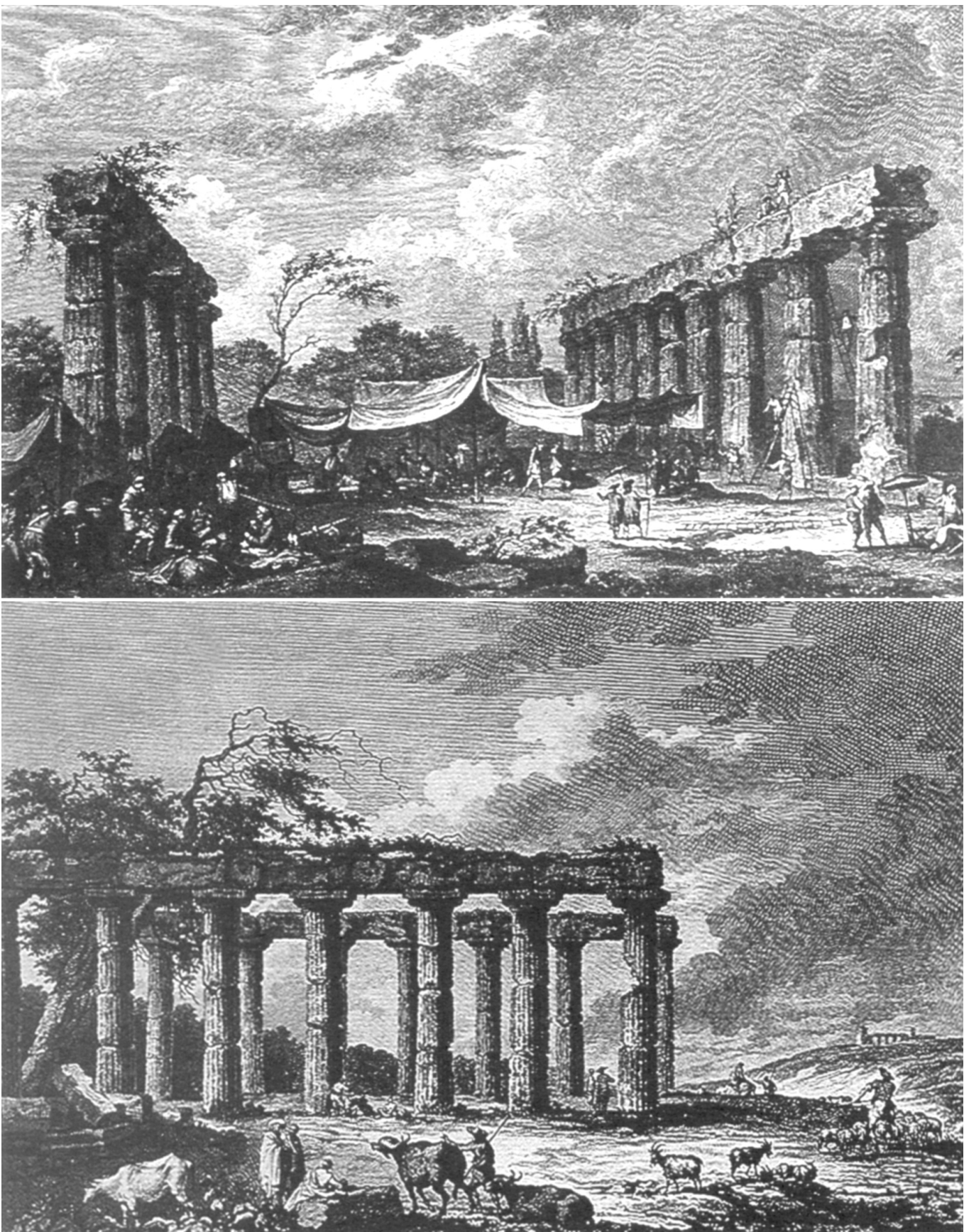

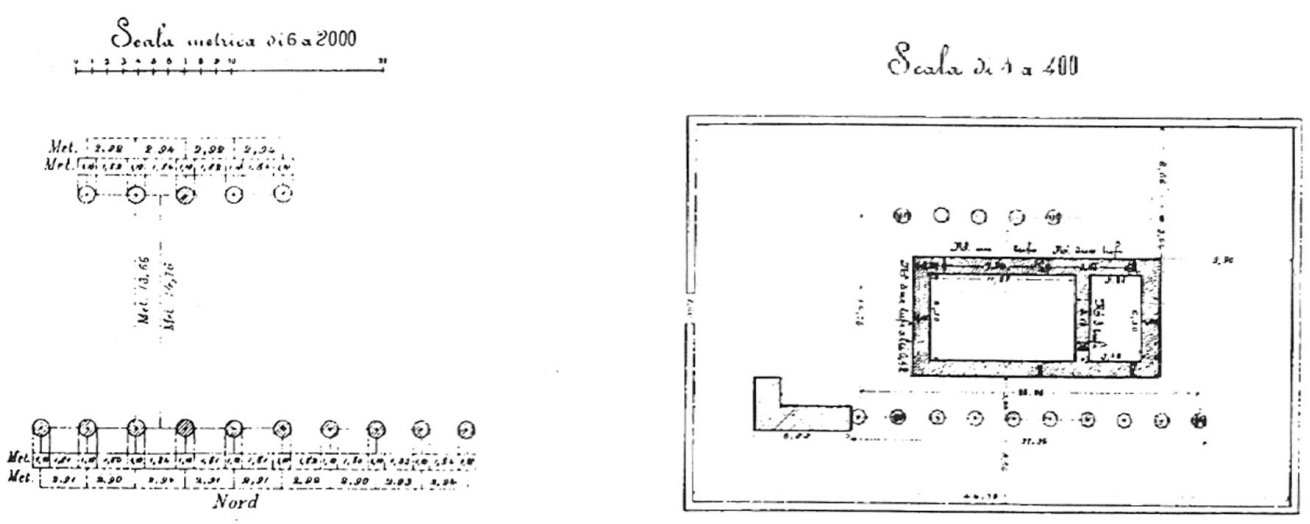

Fig. 3. Pianta del tempio di Hera a Metaponto in cui sono riportate
le fondazioni della cella le fondazioni de
[Lacava $|89|]$.

Fig. 4. Sezione di uno dei capitelli dorici del tempio di Hera (Metaponto) secondo le misurazion effettuate da Sante

Simone nel I 875 [Lacava $|89|]$.
Tar. VIII - Planimetria del Tempio tlelle Colonno Paladino.

Nel rilievo archeologico 'storico', ossia in tutte quelle testimonianze grafiche operate per la restituzione di contesti archeologici nei secoli passati, i disegni ci forniscono informazioni 'datate', cioè permeate dell'impronta culturale dell'autore. "Di fronte ad un disegno datato nascono due problemi interpretativi. II primo riguarda il rapporto instaurato all'origine tra disegnatore e soggetto, rapporto dal quale ebbe origine la raffigurazione e che comporta l'analisi delle relazioni tra due culture, quella relativa all'opera rappresentata e quella relativa all'interprete. II secondo riguarda il rapporto che si instaura successivamente tra l'immagine e l'osservatore" [de Rubertis 1992].

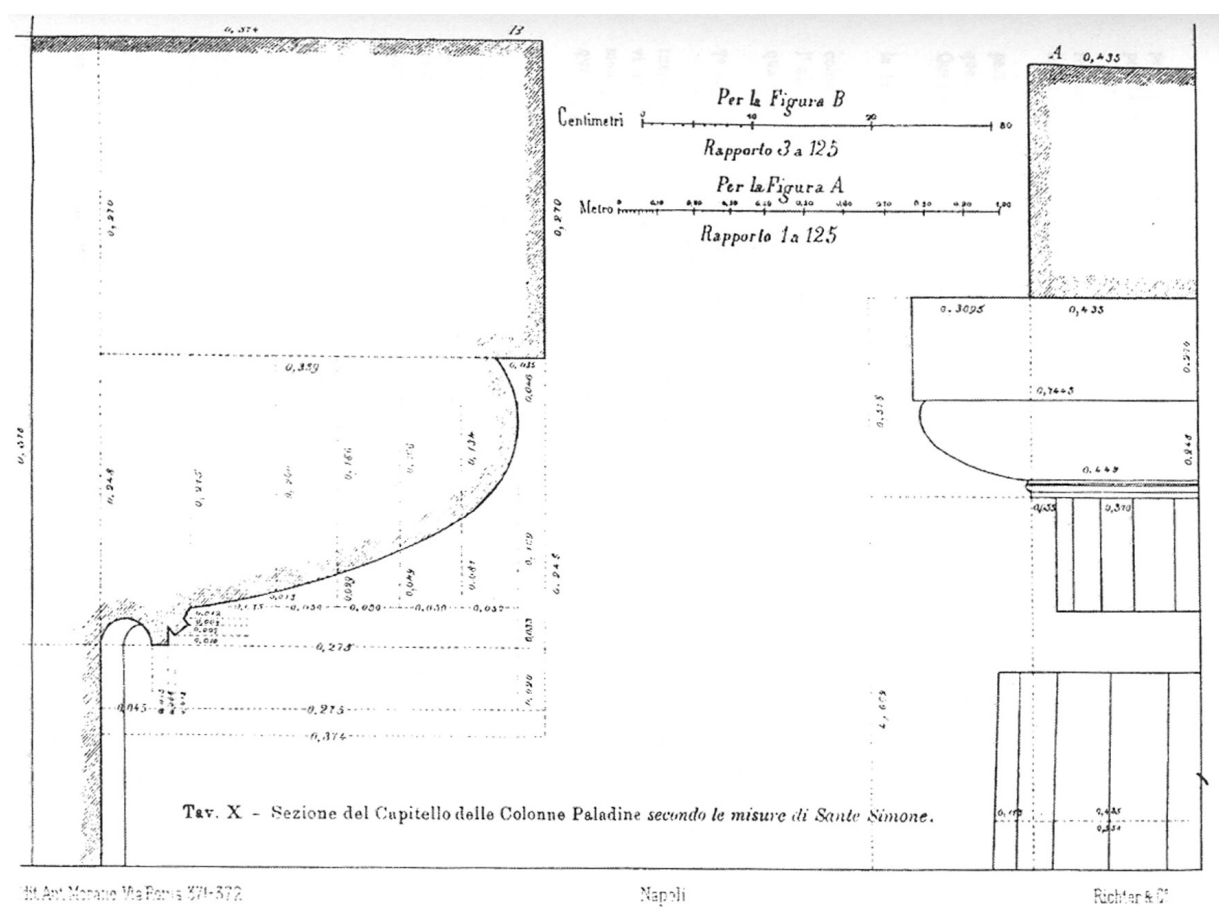


Nello studio dei disegni di rilievo archeologico storici diventa ancora più importante la capacità di interpretare il disegno stesso, provando a decodificare annotazioni grafiche e 'volontà comunicative' dell'autore.

Da queste brevi considerazioni sull'importanza del rilievo e sulla complessità dello studio di quello archeologico storico partono le prime riflessioni sulla necessità interpretativa delle testimonianze iconografiche del passato, che diventano fondamentali per la comprensione dei 'percorsi di conoscenza' degli studiosi che ci hanno preceduto.

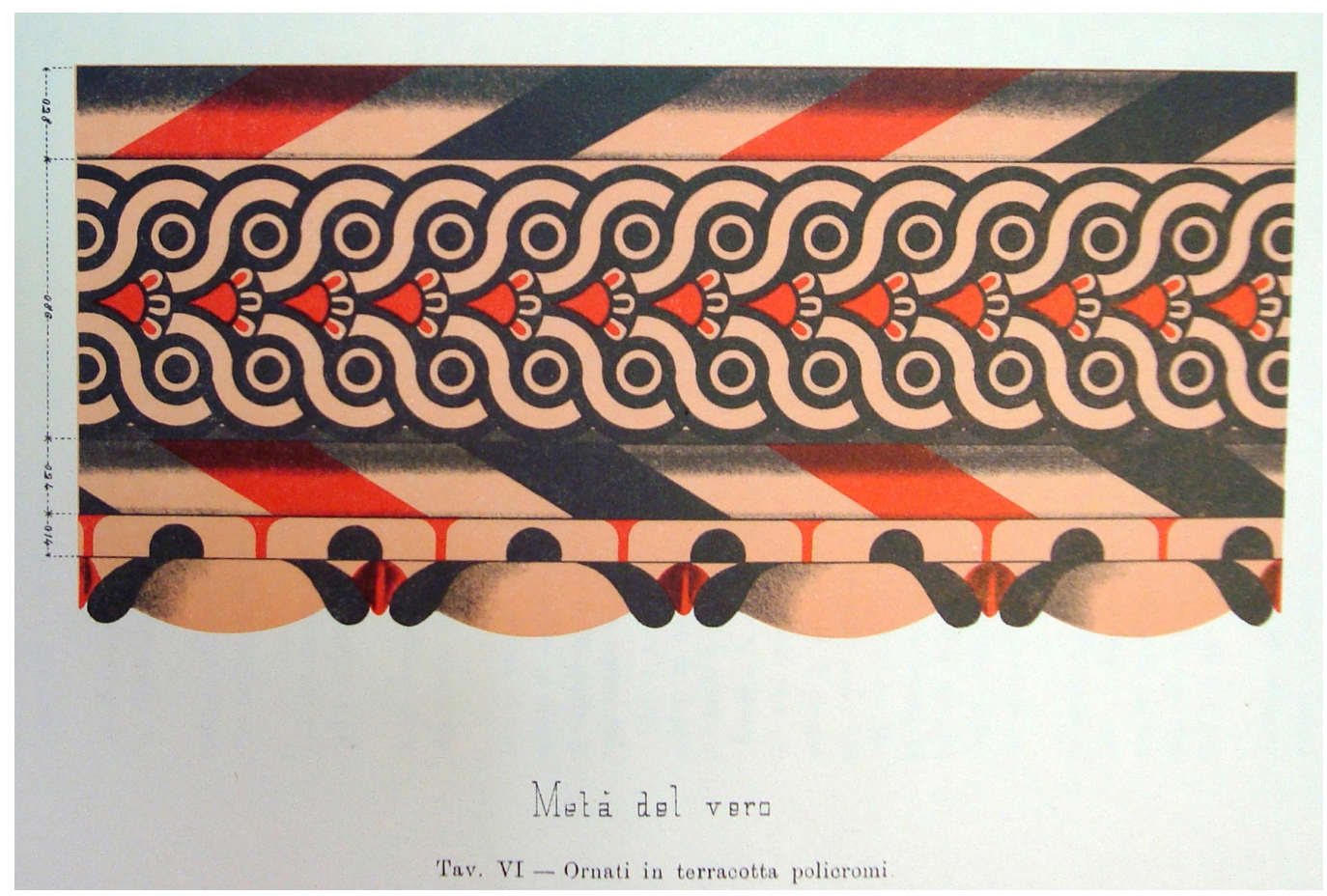

\section{Disegnare la memoria}

La disamina dei documenti d'archivio, conservati presso l'Archivio di Stato di Potenza, ha portato all'analisi di una cospicua documentazione relativa agli scavi archeologici di Metaponto. Documenti di scavo, pratiche per l'espropriazione di terreni con evidenze archeologiche e progetti per la tutela delle rovine del santuario dorico extraurbano dedicato a Hera, più conosciuto come le Tavole Palatine, rappresentano il corpus su cui vale la pena soffermarsi.

È da precisare che la documentazione su Metaponto non è l'unica conservata. Numerosi sono infatti i documenti prodotti, soprattutto tra il XIX secolo e i primi decenni del secolo successivo, per diverse aree lucane in cui erano riportate alla luce, casualmente o con scavi clandestini e autorizzati, testimonianze archeologiche [I].

Ma fatta eccezione per un carteggio relativo agli scavi da farsi nella piazza di Marsico Nuovo, in provincia di Potenza, in cui è inserito un piccolo schizzo grafico esemplificativo dell'area oggetto dell'indagine archeologica [2], nel resto della documentazione non troviamo mai materiali grafici, ma tutto è affidato alla semplice descrizione dei luoghi e degli eventuali oggetti ritrovati. Un caso a sé è dunque rappresentato da quanto prodotto su Metaponto, in provincia di Matera, in cui sovente troviamo allegati disegni di rilievo.

Oltre ai documenti d'archivio, parte del materiale grafico prodotto nel corso del XIX secolo, di cui non si sono conservati gli elaborati originali, è pubblicato in monografie dedicate all'antica città magnogreca. 
Fig. 6. Disegno ricostruttivo (prospetto e sezione) di una cassetta dal tempio urbano di Apollo (Metaponto) in terracotta policroma [Lacava |89|].

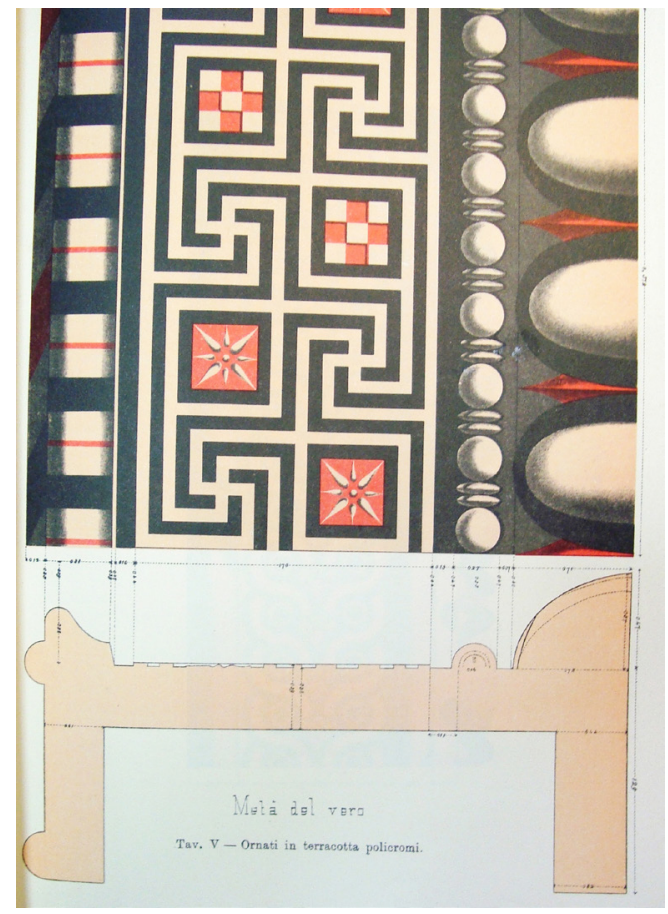

Tra le rovine archeologiche nel territorio di Metaponto di cui ci parlano la letteratura ottocentesca e i documenti d'archivio, sono senza dubbio le già menzionate Tavole Palatine i resti architettonici su cui maggiormente si è concentrata l'attenzione degli studiosi per la loro conoscenza, ma anche per la loro salvaguardia [3]. I ruderi dell'edificio che spicca per monumentalità e stato di conservazione - nel XIX secolo sono ancora in situ quindici colonne, cinque su un lato e dieci su quello opposto, su cui corre ancora parte della trabeazione sono ubicati su una piccola altura sulla sponda destra del fiume Bradano.

Prima proprietà del monastero di san Michele Arcangelo di Montescaglioso e poi di san Lorenzo di Napoli, diventano a seguito della soppressione degli ordini religiosi proprietà dello Stato, per essere posti all'incanto per la vendita poi non conclusasi [Lacava |89|].

Già nel secolo precedente il santuario extraurbano di Hera era stato oggetto di visite da parte dei diversi viaggiatori stranieri che si erano spinti sulle coste del mar lonio alla ricerca delle antiche città di Metaponto ed Eraclea. È in particolare all'esplorazione voluta dai fratelli Richard, Jean Baptiste Claude abate di Saint-Non e Louis, e guidata da Dominique Vivant Denon, che si devono le prime due testimonianze iconografiche delle rovine del tempio greco realizzate da Louis-Jean Desprez (I743-|804) e da Claude-Louis Chậtelet (I7531795) pubblicate nel 1783. Si tratta di due vedute dello stesso monumento da due diverse angolazioni che ne enfatizzano lo stato di abbandono.

Nella seconda metà dell'Ottocento, per garantire una maggiore tutela delle rovine, è realizzato un muro perimetrale di recinzione progettato dallingegnere Galeoni di Taranto e finanziato, tra gli altri, dai Comuni di Montescaglioso, Bernalda, Pisticci e Montalbano, nonché dalla Provincia di Basilicata. L'opera, concepita per evitare l'ulteriore spoliazione del monumento e che troviamo riportata in tutte le planimetrie del XIX secolo, è contestata dagli studiosi che si recano in visita nelle rovine, primo fra tutti Lenormant, i quali sottolineano come l'altezza del muro e la sua poca distanza dalle colonne impediscono la visione del tempio [Lacava |89|].

Come per l'edificio dedicato ad Apollo Licio, anche le Tavole Palatine appaiono spogliate per il recupero di blocchi reimpiegati altrove, ma le indagini archeologiche ottocentesche portano a ipotizzare un suo sviluppo complessivo di 34,29 × 13,66 metri - probabilmente con dodici colonne sul lato lungo e sei su quello corto di ordine dorico - così come indicato nei primi rilievi disegnati. 
Fig. 7. Pianta delle fondazioni del tempio di Apollo Licio a Metaponto [Lacava |89/]. La struttura si presenta con un ingombro di $41,50 \times 22,50$ metri con i fronti più lunghi rivolti a borea e a mezzogiorno. Il disegno ottocentesco document un edificio ormai spogliato, senza traccia della pavimentazione, le cui fondazioni sono realizzate con blocchi di tufo rettangolari poste in opera senza malta.

Fig. 8. Sezioni di uno dei diciotto capitelli di ordine dorico appartenenti domico appartenentia a Metaponto [Lacava a Metaponto [Lacava |89|
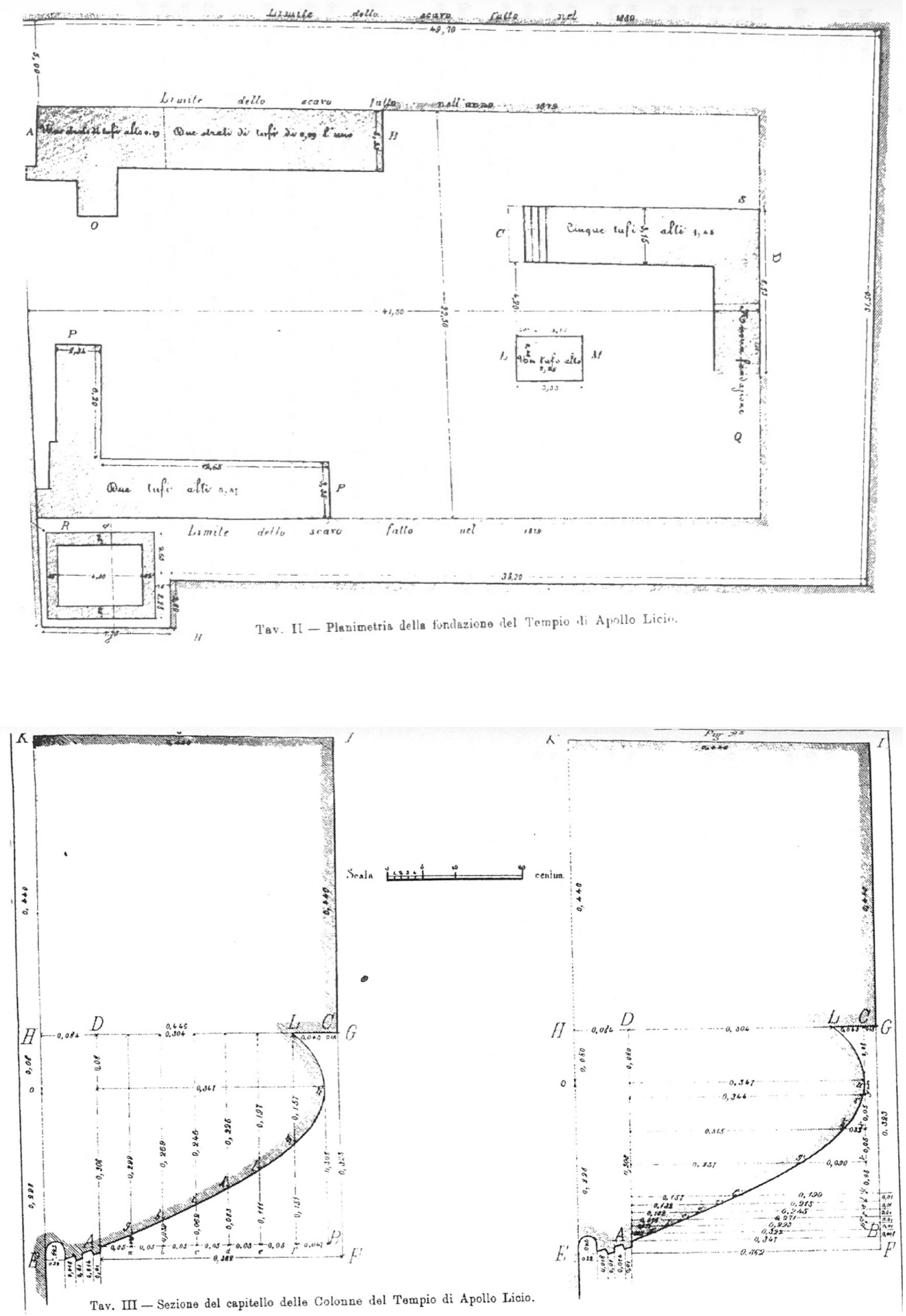
Fig. 9. Planimetria della contrada di Torre di Mare, in agro di Pisticci. con indicazione dell'area da espropriare, per effettuare degli scavi dall'ingegner Carlo Albero Calcaterra nel settembre 1879 [ASPZ Prefettura di Basilicata Atti amministrativi $(1883-$ 1887), b. 80, fasc. 609]

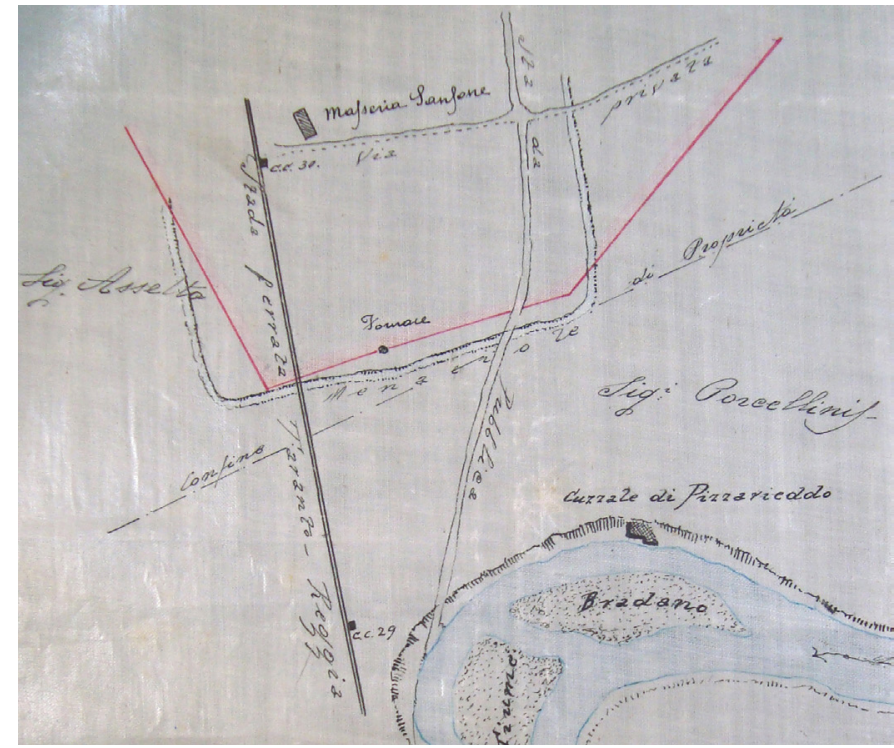

Nel 1825 e nel 1828 il duca francese Honorè De Luynes è a Metaponto dove effettua scavi archeologici durante i quali riporta alla luce alcuni elementi architettonici in terracotta, tra cui dei geison e delle sime con teste leonine, che testimoniano, tra i primi, l'uso del colore nell'architettura antica. Un cinquantennio più tardi elementi simili, posti in origine a coronamento dell'edificio templare dedicato ad Apollo e con tracce di rosso, ocra e nero, sono rinvenuti e documentati anche con interessanti disegni, in cui è proposta una loro ipotesi ricostruttiva, durante nuove campagne di scavo condotte dall'ispettore degli Scavi di antichità Michele Lacava [Lacava I89|].
Fig. 10. "Pianta della zona di terreno da espropriar nella proprietà De
Porcellinis Antonio

(denominata Cuzzale di Pizzarieddu) per gli scavi di Metaponto" disegnata dall'ingegner Carlo Alberto Calcaterra l'otto settembre 1879 [ASPZ, Prefettura di Basilicata, Atti amministrativi (1883 1887), b. 80 , fasc. 609].

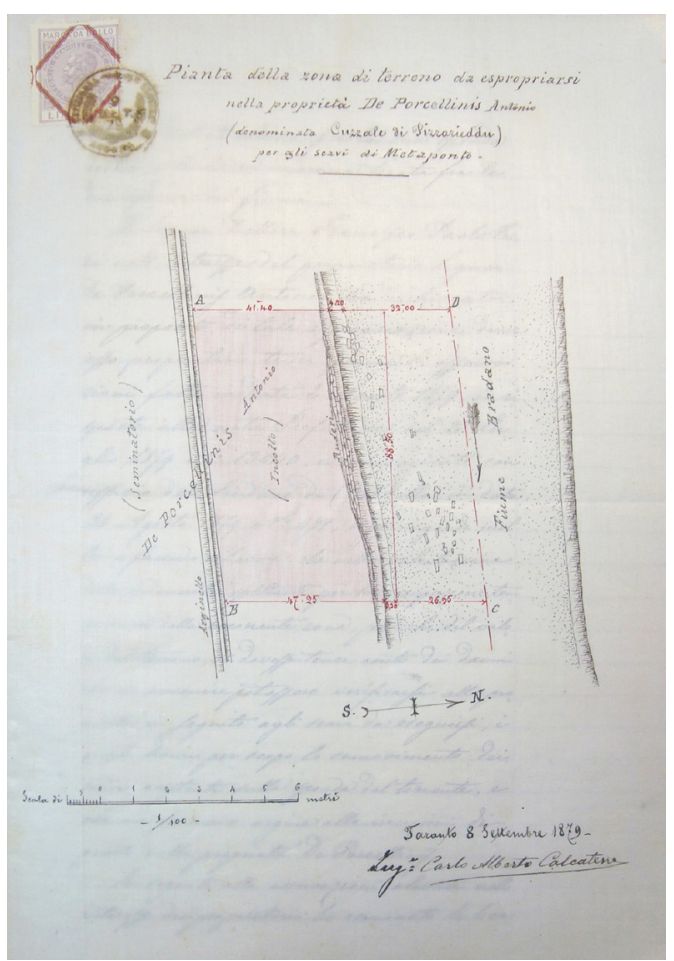


Fig. I I. "Schizzo

planimetrico della localita denominata 'Le Colonn Paladine' per esproprio di suolo da dichiararsi di pubblica utilità". Nel disegno è anche riportato il regio tratturo che collegava la Calabria con la Puglia e il progetto di deviazione dello stesso [ASPZ Prefettura di Basilicata, Atti amministrativi (18981902), b. 23, fasc. 31].

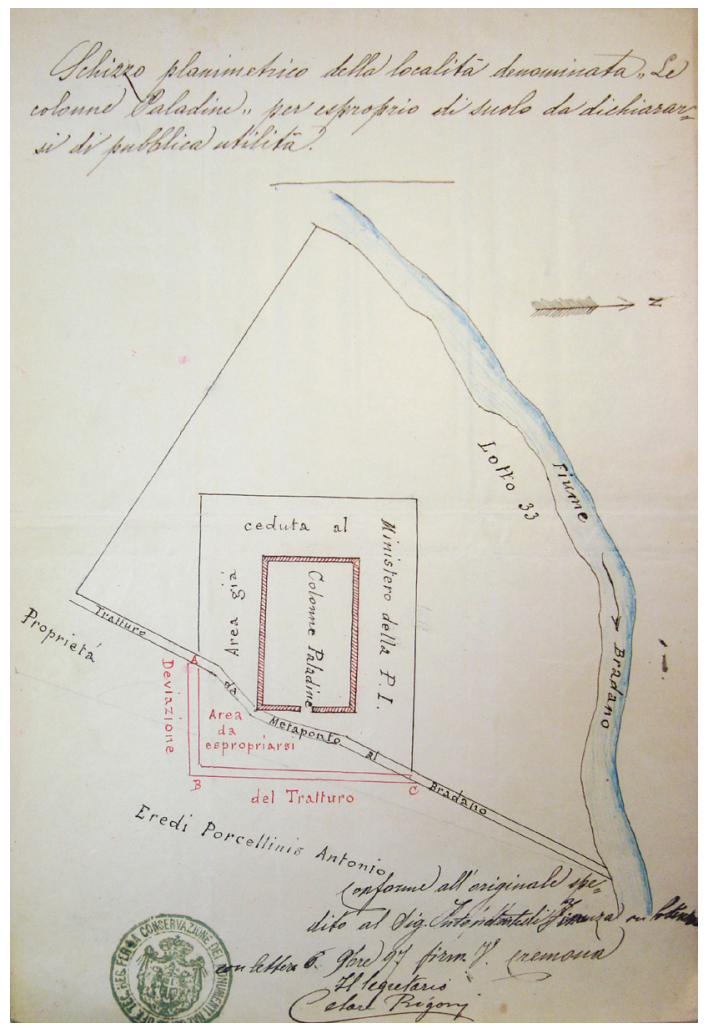

Riprese le indagini archeologiche da parte di quest'ultimo nel 1877, due anni più tardi è presentata l'istanza per il riconoscimento di un'indennità, per l'occupazione temporanea di un anno, al signor Antonio De Porcellinis proprietario di un terreno in località Cuzzale di Pizzarieddu, nella contrada di Torre di Mare in agro di Pisticci. Tale richiesta è avanzata "allo scopo di praticarvi degli scavi, e propriamente disseppellire alla sponda del Bradano e nel suo alveo i pezzi di colonna e architravi, appartenenti a un sontuoso tempio e ora giacenti sotto il limo del fiume" [4]. L'incarico per fissare l'indennità di esproprio è affidato all'ingegnere governativo delle ferrovie Calabro-Sicule Carlo Alberto Calcaterra di Taranto che, sentite le indicazioni e dopo aver fatte le opportune misurazioni, procede con il disegno delle piante dell'area. Si tratta di due elaborati: nel primo è individuata, a una scala più vasta, la proprietà del signor De Porcellinis, nel secondo, a una scala di maggior dettaglio, è invece indicata con il colore rosso la zona che sarà interessata dagli scavi archeologici.

Qualche anno più tardi, nel I895, è avanzata l'ipotesi, per una maggior salvaguardia del santuario di Hera, già chiuso da un muro di recinzione come si è detto, di stabilire una fascia di rispetto lungo i lati del monumento. È quindi necessario procedere all'espropriazione di una porzione di terreno, appartenente agli eredi De Porcellinis, attiguo al tempio a levante e nell'angolo sud-est [5]. Inoltre, sono anche condotti degli accertamenti per l'individuazione del tracciato del regio tratturo che dalle Calabrie conduceva alle Puglie e, in particolare, del tratto che univa il fiume Basento al Bradano. Parte del detto tratturo ricadeva nella fascia di rispetto indicata per la tutela del monumento antico e, dunque, è proposta una sua deviazione lungo il perimetro della fascia stessa. È quanto si desume anche da alcune planimetrie esemplificative allegate ai carteggi [6].

Seppur esigui, questi documenti denotano una prima sensibilità per la rappresentazione grafica nell'ambito della documentazione del patrimonio archeologico, spesso affidata ai soli testi scritti.

Tavole di studio, planimetrie per perizie tecniche e disegni dal vero documentano un patrimonio archeologico in una regione ancora poco conosciuta, qual era la Basilicata, tra la fine del XVIII e il XIX secolo. 


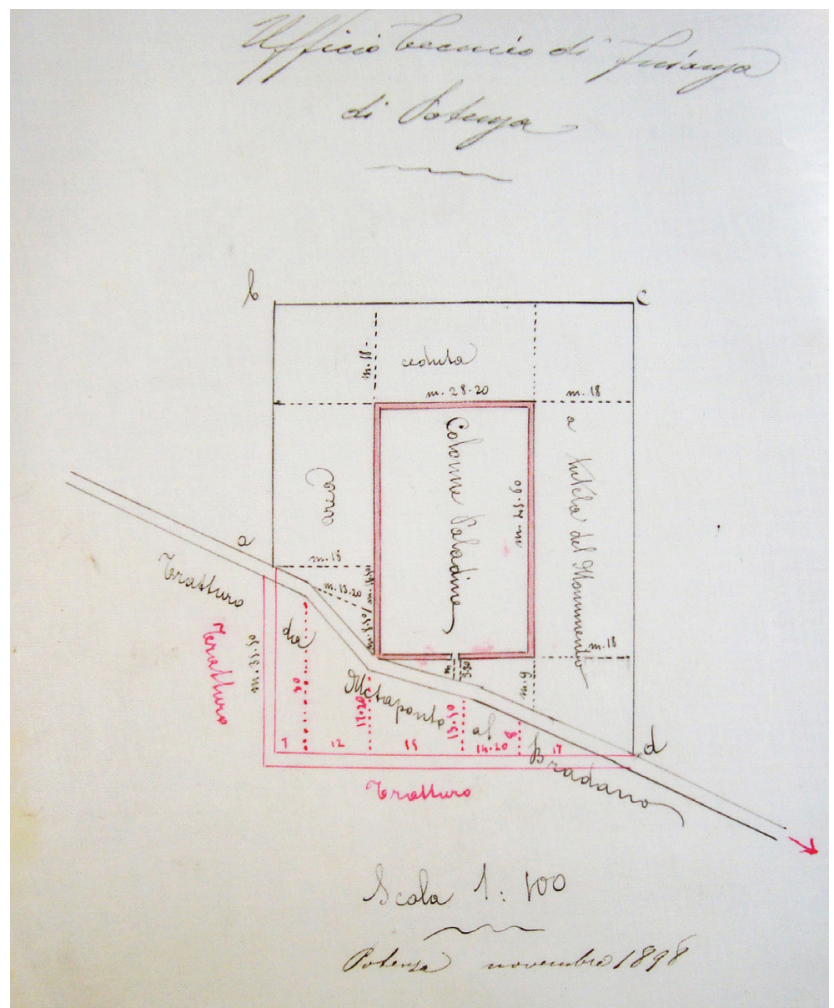

\section{Paesaggi archeologici tra narrazione e documentazione: note conclusive}

Lo studio delle fonti documentarie, seppur disomogenee cronologicamente e per alcuni aspetti frammentarie, e l'approfondimento della letteratura sulla tematica della documentazione archeologica lucana, consentono di tracciare il nuovo interesse degli intellettuali ottocenteschi per le rovine archeologiche da documentare e tramandare alle generazioni future, secondo una più ampia visione 'romantica' dell'archeologia del tempo.

Un approccio interdisciplinare, mirante alla corretta interpretazione dei documenti, ci consente dunque di ricostruire da una parte la storia dell'archeologia in Basilicata e dall'altra di documentare, attraverso una mirata analisi delle testimonianze grafiche, le trasformazioni del 'paesaggio archeologico' e il ruolo, nel più ampio dibattito scientifico del tempo, avuto dagli studiosi ottocenteschi di antichità che, con relazioni descrittive e tavole di disegno, presentavano i risultati dei loro studi sull'architettura antica e sull'utilizzo del colore nella stessa. Uno studio dunque, quello appena presentato, che vuol rappresentare un tassello in un più ampio discorso di conoscenza di queste testimonianze grafiche che, messe a sistema anche con altre riguardanti contesti geografici meno noti sino ad oggi, ci permette di cogliere appieno una conoscenza archeologica del territorio nel XIX secolo che passa soprattutto attraverso il disegno.

\section{Note}

[ I] Per un quadro completo della documentazione riguardante la ricerca archeologica in Basilicata conservata presso l'Archivio di Stato di Potenza si veda:Verrastro 1997

[2] Archivio di Stato di Potenza, d'ora in poi ASPZ, Intendenza di Basilicata, b. (busta) I337, fasc. (fascicolo) 7.

[3] Nel XIX secolo sono ancora visibili anche le rovine del tempio di Apollo Licio, comunemente detto nella tradizione popolare 'chiesa di Sansone', dall'episodio biblico in cui Sansone distrugge il tempio dei Filistei facendosi seppellire dalle sue rovine. Di questo edificio metapontino ne parla il duca De Luynes: "i suoi rottami ammucchiati attestavano una rovina totale e rapida: i straripamenti del Bradano ne hanno seppellito la più gran parte sotto un grosso strato di limo, e donde escono alcuni fusti di colonne e molti capitelli dorici di grande dimensione, ma completamente irreconoscibili. Quasi alla superficie del suolo si trovano in gran numero avanzi di modanature, di ovoli, di greche, di teste di leoni" [Lacava I89|]. 
[4] ASPZ, Prefettura di Basilicata, Atti amministrativi (1 883-/ 887), b. 80, fasc. 609, verbale per il riconoscimento dell'indennità di esproprio dell'otto settembre 1879.

[5] ASPZ, Prefettura di Basilicata, Atti amministrativi ( I 898-1902), b. 23, fasc. 3 I, lettera al prefetto di Basilicata dall'architetto dell'ufficio tecnico di finanza dell'otto ottobre 1897; lettera al prefetto di Basilicata del 18 giugno 1898.

[6] ASPZ, Prefettura di Basilicata, Atti amministrativi (1898-1902), b. 23, fasc. 31, lettera al prefetto di Basilicata del 17 dicembre 1898.

\section{Riferimenti bibliografici}

Cardone Vito (20।4). Viaggiatori d'architettura in Italia. Da Brunelleschi a Charles Garnier. Salerno: Università degli Studi - libreriauniversitaria.it.

Carpeggiani Paolo, Patetta Luciano (a cura di). (1989). Il disegno di architettura. Milano: Edizioni Angelo Guerini e associati.

Caserta Giovanni (a cura di). (2005). Viaggiatori stranieri in terra di Lucania Basilicata. Venosa: Osanna Edizioni.

Corti Siro ( I 889). Le province d'Italia sotto l'aspetto geografico e storico, Provincia di Potenza. Torino: G. B. Paravia.

Cundari Cesare et al. (2012). L'espressione grafica integrata per la documentazione e la conoscenza del patrimonio culturale. In Gráfica del diseño: tradición e innovaciones. Atti del IV congreso international de Expresión Gráfica en ingeniería, arquitectura y carreras afines. 17- 19 ottobre 2012 Universidad Nacional De La Plata. La Plata: GMG, pp. 367-37I.

De Rubertis Roberto (1992). Ermeneusi. In de Rubertis Roberto, Soletti Adriana, Ugo Vittorio. Temi e codici del disegno d'architettura. Roma: Officina Edizioni, pp. 179-226.

Guidano Guido ( 199 I). Intorno all'architettura. In Guidano Guido, Cerotto Paolo, Conte Antonio, Tolla Enza. Disegno, teoria e applicazioni. Potenza: Edizioni Ermes, pp. 9-20.

Lacava Michele ( 89 |). Topografia e storia di Metaponto. Napoli: Morano.

Ludovico Antonio (199I). Rilevamento architettonico e topografico metodi e strumenti nei secoli XVIII e XIX. I catasti geometrici preunitari e la misura generale del Granducato di Toscana. Roma: Edizioni Kappa.

Principe llario (|99|). Atlante storico della Basilicata. Cavallino (Lecce): Capone.

Sassu Rita (2019). Metaponto: II Tempio B del santuario urbano. In Giulierini Paolo, Giacco Marialucia (a cura di). Museo Archeologico Nazionale di Napoli. La collezione Magra Grecia. Milano: Electa, pp. I76- 179

Settembrino Giuseppe ( 1996). Archeologia e natura della costa ionica lucana. Il viaggio e l'evento. Venosa: Appia 2 editrice.

Tolla Enza, Bixio Antonio (2012). Un laboratorio per il rilievo. Fisciano-Salerno: Edizioni CUES

Verrastro Valeria (1997). Fonti per la storia dell'archeologia in Basilicata nell'Archivio di Stato di Potenza. In Bollettino Storico della Basilicata, n. 13, pp. I59-196.Venosa: Edizioni Osanna.

\section{Autore}

Giuseppe Damone, Università degli Studi della Basilicata, giuseppe.damone@unibas.it

Per citare questo capitolo: Damone Giuseppe (2020). Disegnare la memoria. I primi rilievi archeologici ottocenteschi in Basilicata/Edit the memory. The first archeological surveys in Basilicata of the XIXth Century. In Arena A., Arena M., Brandolino R.G., Colistra D., Ginex G., Mediati D. Nucifora S., Raffa P. (a cura di). Connettere. Un disegno per annodare e tessere. Atti del $42^{\circ}$ Convegno Internazionale dei Docenti delle Discipline della Rappresentazione/Connecting. Drawing for weaving relationships. Proceedings of the 42th International Conference of Representation Disciplines Teachers. Milano: FrancoAngeli, pp. 3203-3224. 


\section{Edit the Memory. The First Archeological Surveys in Basilicata of the XIX Century}

Giuseppe Damone

Abstract

A new feeling for archeological ruins contributes to production of numerous writings and drawings starting from the XVIII century, especially after the discovery of the cities of Pompei and Ercolano destroyed by Vesuvio's eruption in 79 AD, which became the hearth of scientific debate.

It is in this contest that the first documentation of lucanian archeological heritage was produced, during the XIX century. That is what emerges from an analysis of the material stored at the State Archive of Potenza where first drawings were found as attachments to some surveys realized for excavation and restoration works in the suburban sanctuary of Hera, in Metaponto, also known as Tavole Palatine.

Another important trace of graphic documentation of architectural and archeological heritage is also included in 19th century literature, a period where the first scholars of antiquity organized excavation and study campaigns of remains that had been out of the academic debate until that time condemned for many centuries to ruin.

These documents, even if in small numbers, show a first feeling for graphic representation in the wider documental contest of archeological heritage of Basilicata often demanded only to written texts.

Keywords

documentation, archeology, archival surveys.

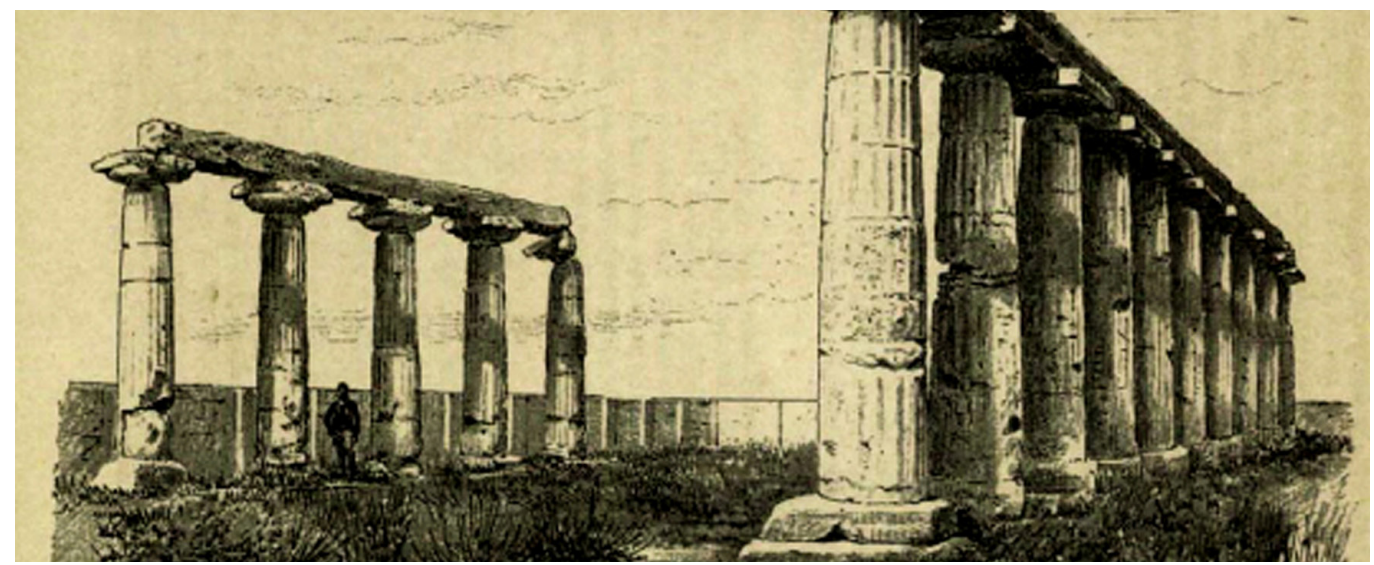




\section{Introduction}

The study of architectures or historic architectural complex has a central role for the knowledge of what inherited from the past and it represents an important piece to bring these evidences to the future. The documentation of these realities guarantees the memory by using surveys on different scale of representation.

Documentation of cultural heritage represents a specific field "where different forms of graphical expression complement each other" [Cundari et al. 20 I2].

The demand to document architectures and ruins is not only a current issue, but it has its origins since 'the history of human knowledge' and in the need of man to represent everything surrounded him. To create a drawing means to be able to narrate making drawing an important and irreplaceable tool of communication.

During centuries different techniques of drawing have been applied, but they all start from the same cornerstone, the power of observation. There is no architectonic building, portion of city or landscape without an attentive and prior phase of observation.

"The drawing is also an instrument of universal representation, extremely quick to describe, to visualize and to communicate" [Guidano 199/], becoming more understandable and immediate than a written text by making simple prefigure a building or a portion of architectural space faster than a verbal or written description.

Built realities and pieces of landscape are visualized on a drawing sheet through the survey drawing.

The survey allows to recognize the process for the knowledge of an object through the data collection later returned by graphic drawing, but it permits also to organize information with a conscious involvement and so the interpretation of surveyor is important to re-elaborate a documentation in a critical way.

In the historic archeological survey, that includes all the graphic evidences produced to describe archeological contests in the past centuries, drawings give us dated information, rich of cultural mark of the author.

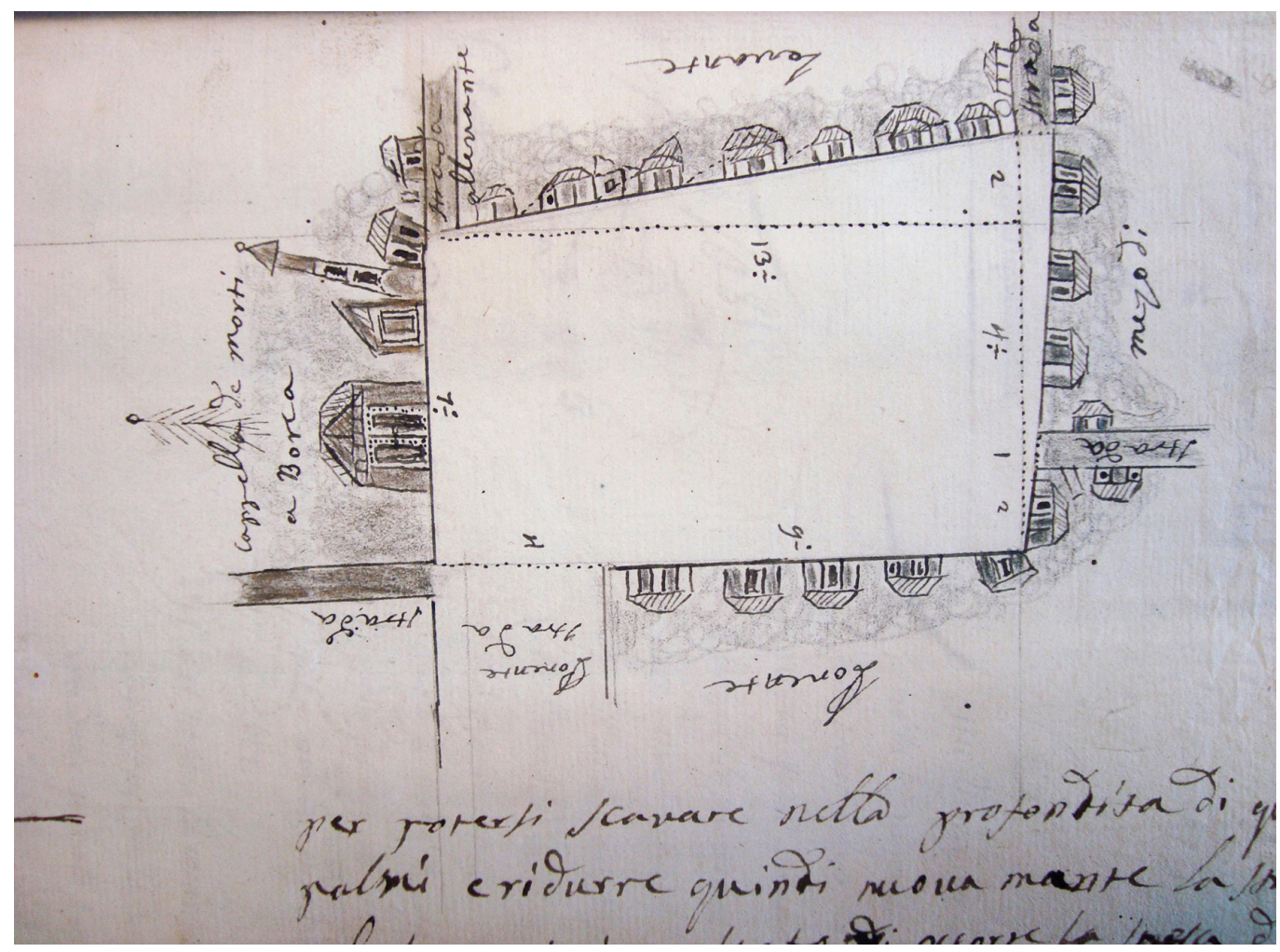


Fig. 2. Views of the

ruins of Hera Temple in

Metaponto by Louis-lean

Desprez (at the top) and

by Claude-Louis Châtelet

(low), published in the

work Voyage pittoresque

in 1783.
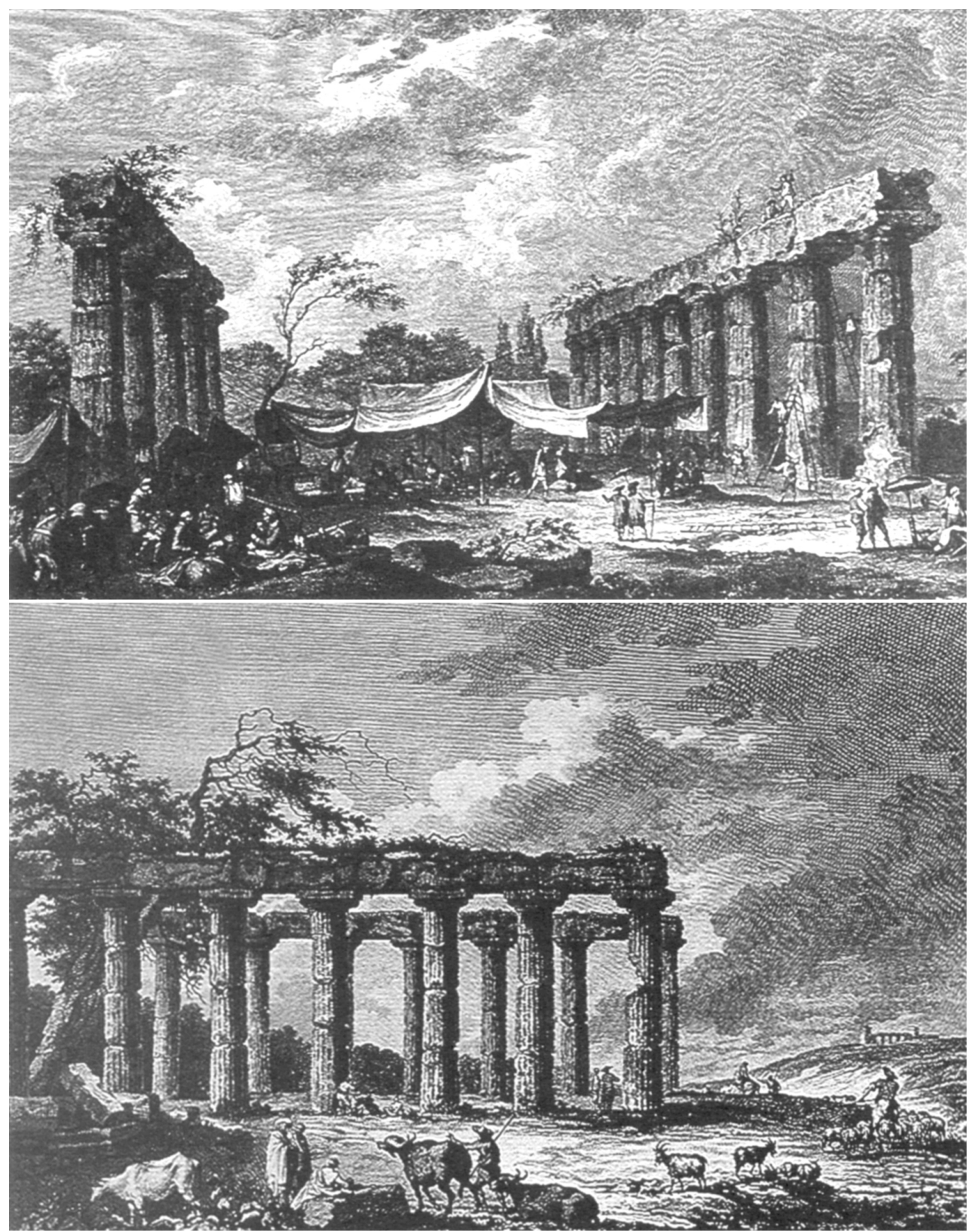

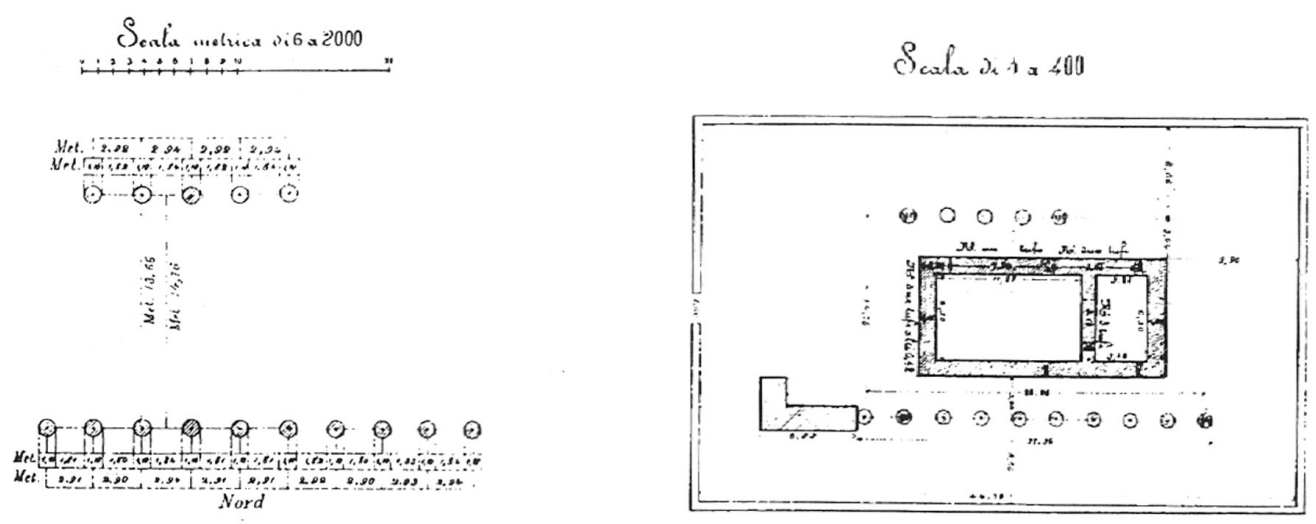

Fig. 3. Plan of Hera temple in Metaponto where the foundations of the cell are shown [Lacava |891].

Fig. 4. Section of one of the Doric capitals of the Hera temple (Metaponto) as measured by Sante Simone in 1875 [Lacava $|89|]$.
Tar. VIII - Planimetria del Tempio tlelle Colonno Paladino.

"Faced with a dated drawing there are two interpretative problems. The first is about the relationship established at the beginning between author and subject, relation from which the representation took its origin and which involves the analysis of two cultures, the one related to the represented work and that related to the author. The second one concerns the connection that later develops between image and viewer" [de Rubertis 1992].

For the study of historic archeological drawings of survey becomes really important the ability to explain the drawing trying to decode graphic notes and 'communicative will' of the author.

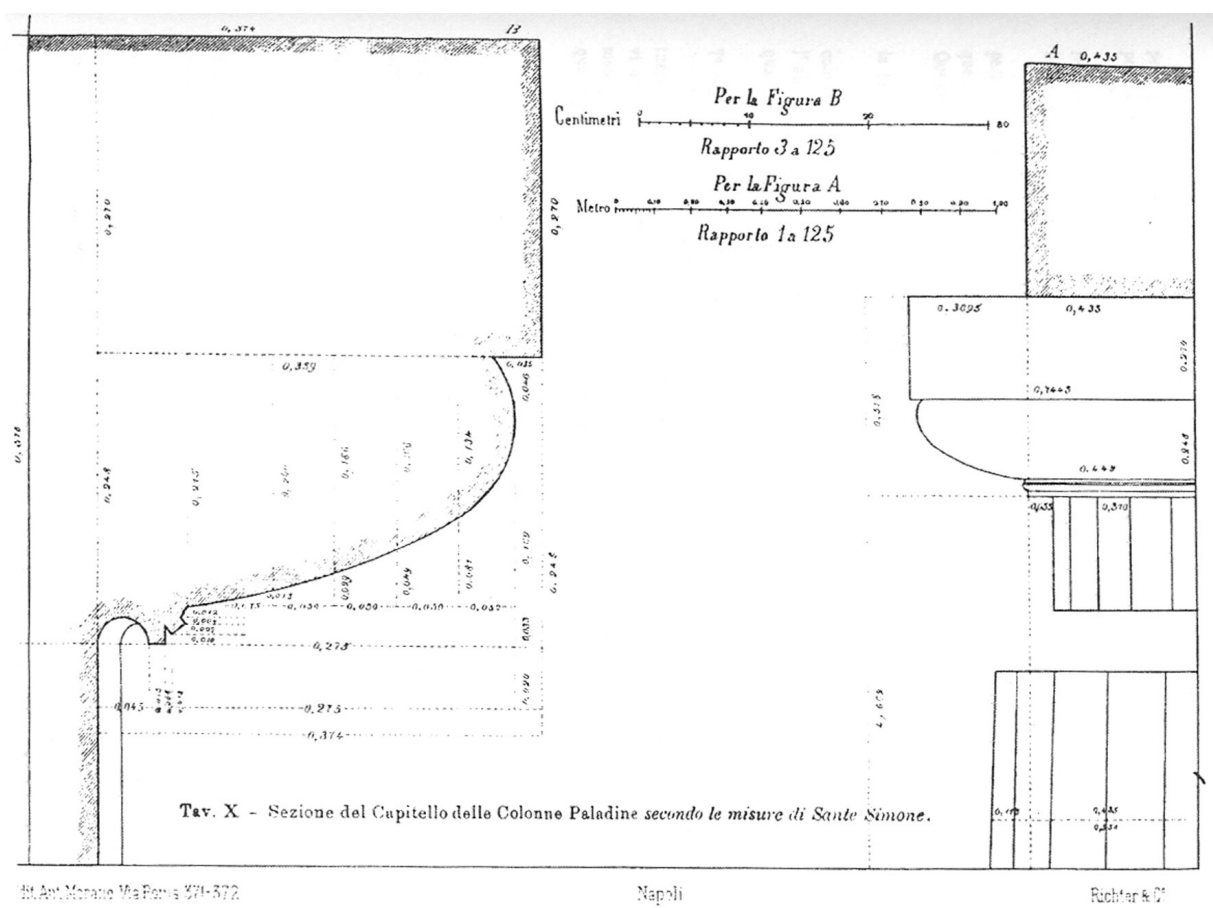


First reflections about the need for the explanation of iconographic proofs of the past to understand the knowledge paths of the scholars before us, start from these considerations about the importance of survey and about the complexity of historic archeological survey.

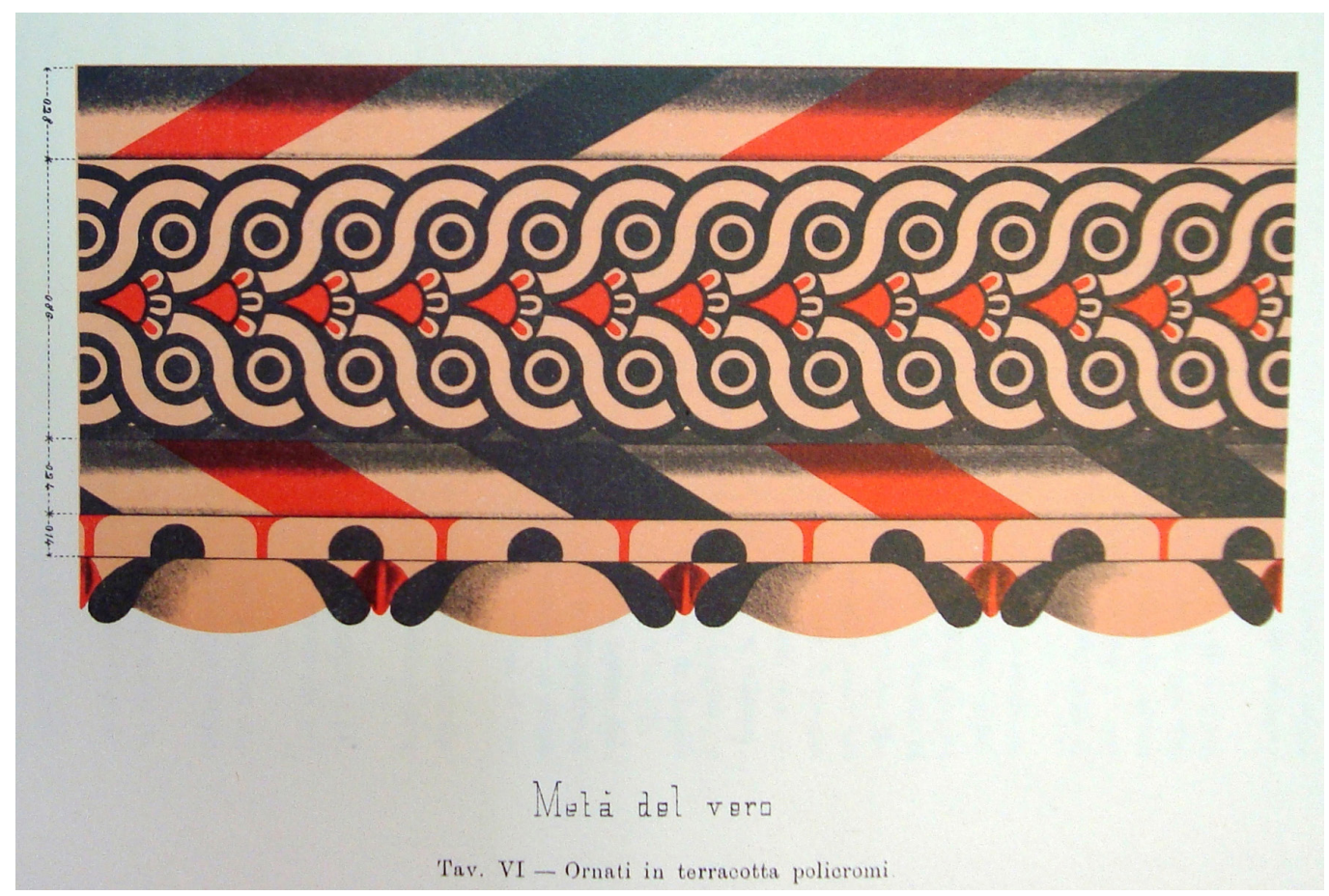

\section{The representation of the memory}

The analysis of archival documents stored at State Archive of Potenza, brings to the examination of a conspicuous documentation about archeological excavations of Metaponto. Excavation documents, paperwork for the expropriation of lands with archeological evidences and projects for the protection of the suburban ruins of the doric sanctuary dedicated to Hera, better known as Tavole Palatine, represent the corpus which requires closer examination.

It is proper specify that the documentation about Metaponto is not the only kept. Several documents are produced, especially between the XIX century and the early decades of the $X X$ century, about various lucanian areas where archeological evidences were accidentally dug out by authorized or secret excavations [I].

Except for documents related to excavations concerning Marsico Nuovo's square, in Potenza's territory, where it is attached a small sketch of the area interested by archeological invastigations [2], for other documents we do not find graphic attachments, everything is entrusted to a simple description of places and found objects.

The case of Metaponto, in the Province of Matera, is unique where we often find attached drawings of survey.

Part of graphic material produced during the XIX century of which we have no original documents was published in monographs dedicated to the ancient city of Magna Grecia. Among archeological ruins in Metaponto's territory of which the archival documents and 
Fig. 6. Reconstruction drawing (perspective and section drawings) of a polychrome earthenware pollo (Metaponto) [Lacava $|89|]$.

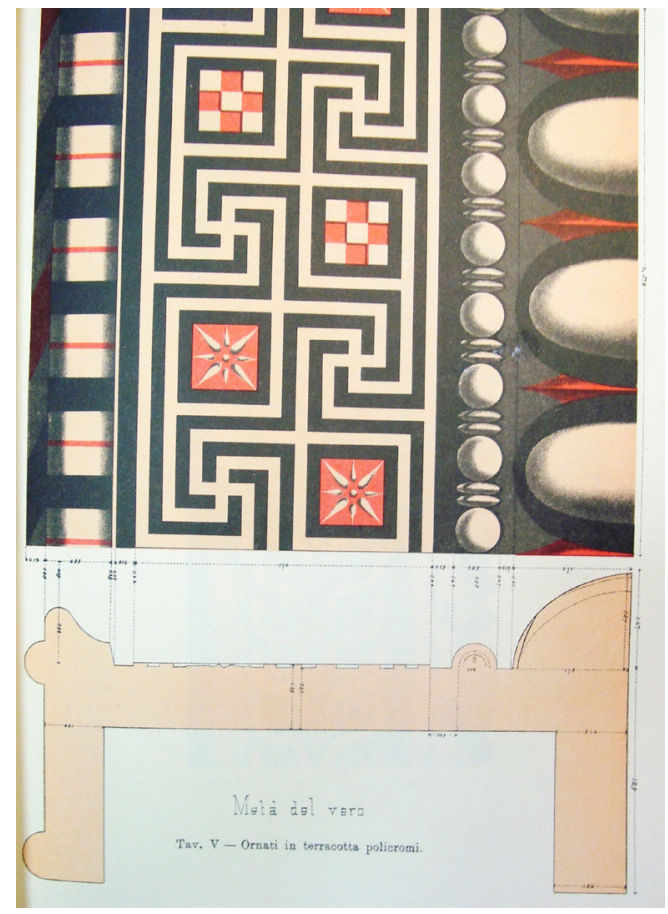

the 19th literature told us, Tavole Palatine are mainly the ruins on which more it is focused the attention of scholars to promote their knowledge and also their protection [3]. The ruins of the building, that stands out for its monumental nature and conservation status, are located on a small hill on the right bank of the Bradano river - in the XIX century fifteen columns are still on site, five columns on the one side and ten on the opposite side, where in the upper part the entablature runs for the entire length.

They belonged at first to the Monastery of St Michel the Archangel of Montescaglioso and then of St Laurence of Naples, later they became State property as a consequence of the abolition of religious orders to be put on auction but not concluded [Lacava I 89 I]. In the previous century the suburban sanctuary of Hera had already been subject of visit by various foreign travellers who arrived on the coasts of lonian Sea in searching for ancient city Metaponto and Eraclea.

It is through the exploration wanted by two brothers Richard, Jean Baptiste Claude abbot of Saint-Non and Louis, headed by Dominique Vivant Denon, that we have the first two iconographic evidences about the ruins of Greek temple realized by Louis-Jean Desprez (I743- I 804) and by Claude-Louis Chậtelet (1753- 1795) published in 1783. They are two views of the same monument but from two different points of view which emphasize its state of abandonment.

In the second half of the XIX century a perimeter wall was built to ensure a greater protection to the ruins, it was designed by engineer Galeoni from Taranto and it was funded by the municipalities of Montescaglioso, Bernalda, Pisticci, Montalbano and by Province of Basilicata.

The structure was essential to avoid further sacking of the monument and its greater protection, we find it represented in all the maps from the XIX century, it was contested by scholars who visited ruins, first of all Lenormant, they remarked how the wall was too high and close to the columns blocking the vision of the temple [Lacava I89 I].

Tavole Palatine, as the temple to Apollo Licio, was despoiled of its block of stones to be re-used somewhere else, archeological investigations in the XVIII century suggest its overall development of 34,29 × 13,66 meters - probably it counted twelve columns on the long sides and six on the shorter sides - as shown from the first sketches of survey. In 1825 and in 1828 the French Duke Honorè De Luynes was in Metaponto where he 
Fig. 7. Foundations plan of the temple of Apollo Licio in Metaponto (Lacava 891). The building takes $41,50 \times 22,50$ meters, with the main facades facing North and South. The 19th century drawing documents a building deprived of its flooring where the foundations where the foundations

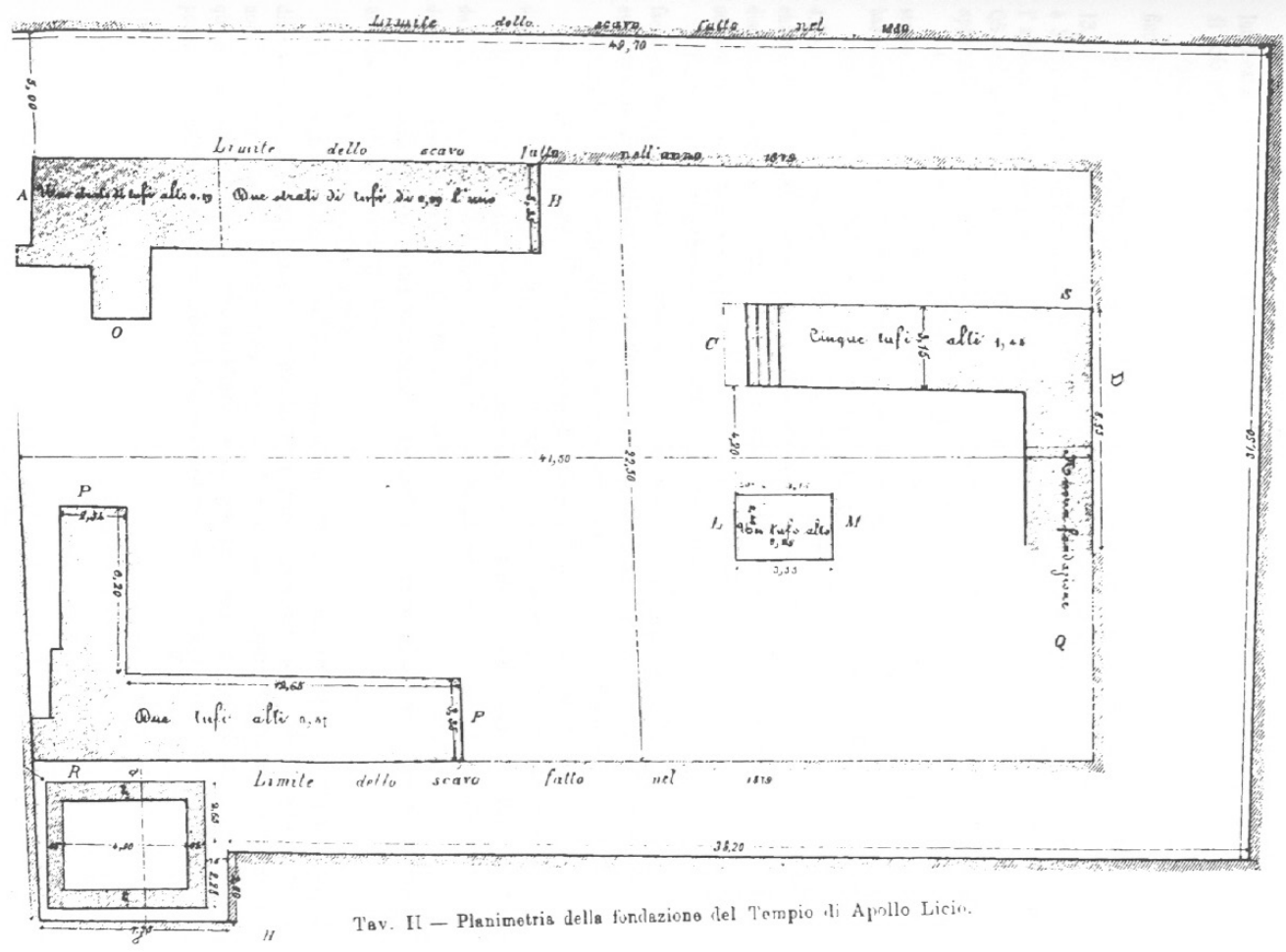

Fig. 8. Section of one of the eighteen Doric capitals belonging to the temple of Apollo Licio in Metaponto [Lacava in Metapd
$\mid 891]$.

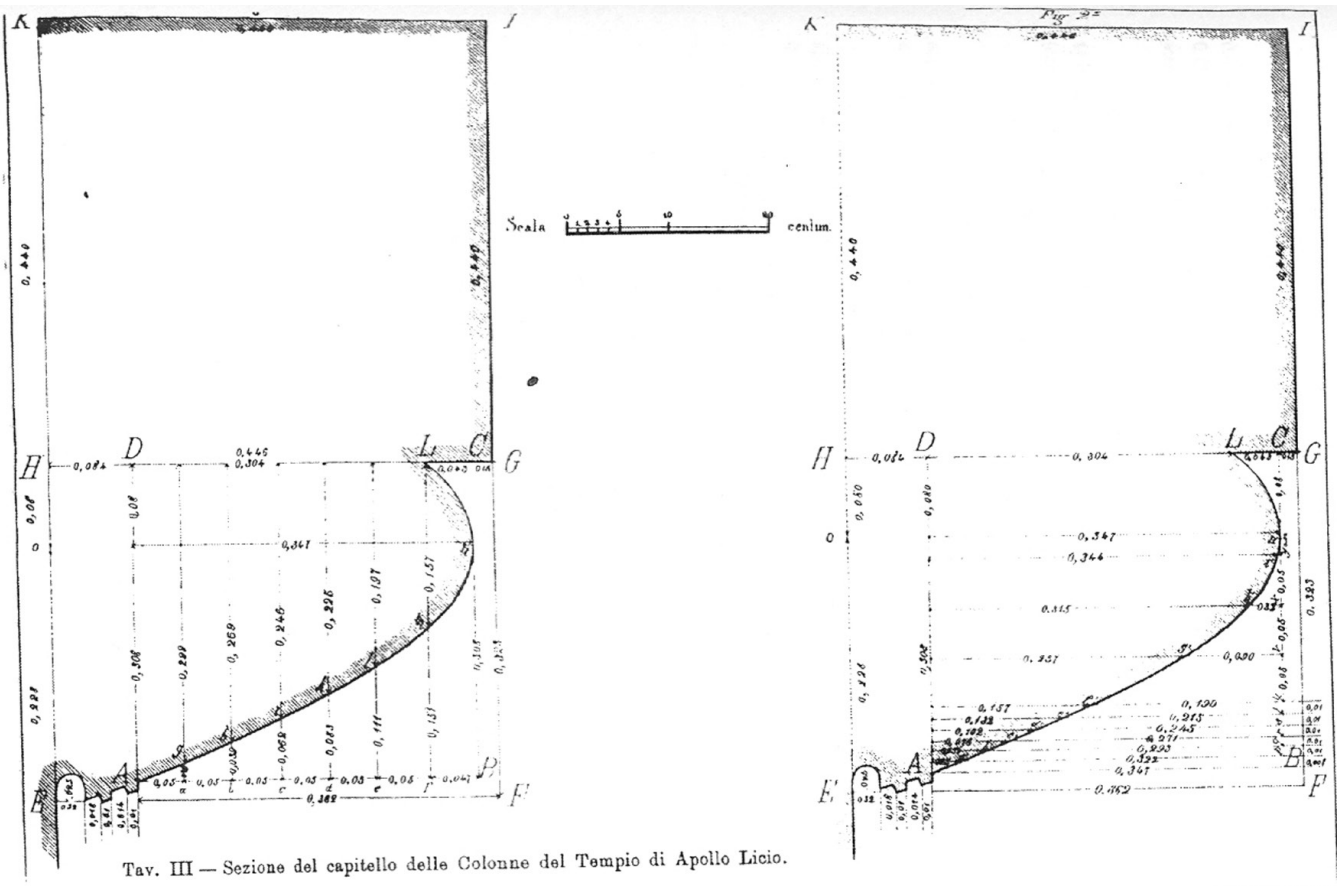


Fig. 9. Torre di Mare map, in the country of Pisticci with information on the land to be expropriated for the archeological

excavation engineer Carlo Albero Calcaterra on September 1879 [ASPZ 1883-1887, b. 80 , fasc. 609 ]

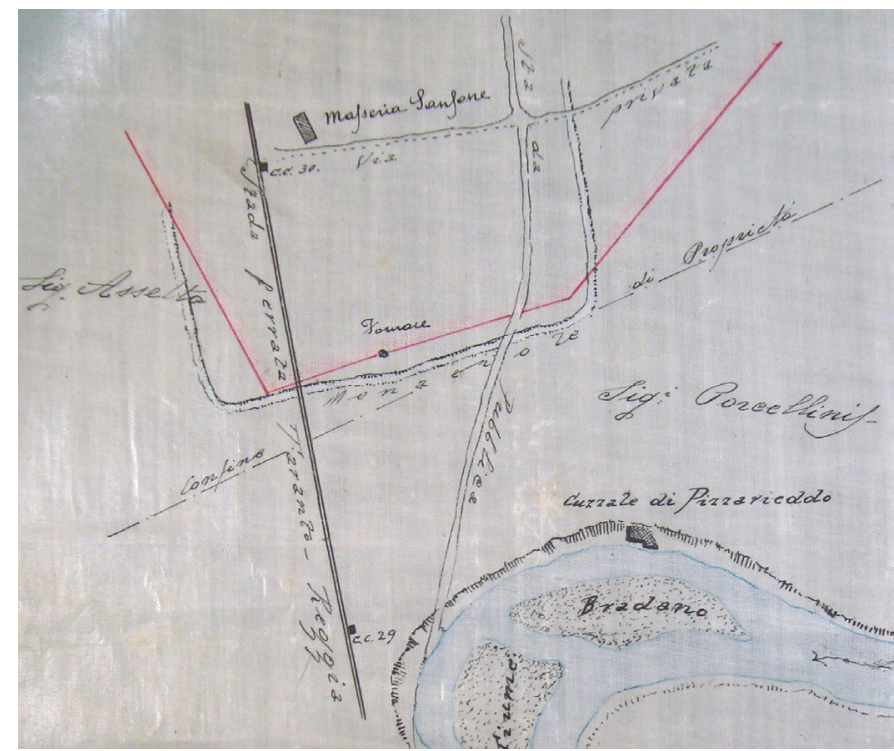

carried out archeological excavations in which architectonic terracotta elements were uncovered, in particular geison and sime with lion heads which evidence the use of color in the ancient architecture.

Fifty years later similar elements with traces of colors black, red and ocher have been revealed, at the origin they were used to crown the temple dedicated to Apollo, interesting drawings documented them, including also an hypothesis of reconstruction, during the new excavation campaigns carried out by the Supervisor of Ancient Excavations, Michele Lacava [Lacava |89|].
Fig. 10. Map of the land to be expropriated property of De Porcellinis Antonio (known as Cuzzale
di Pizzarieddu) for Metaponto excavations drawn by engineer Calcaterra on September 81879 [ASPZ, I8831887, b. 80 , fasc. 609].

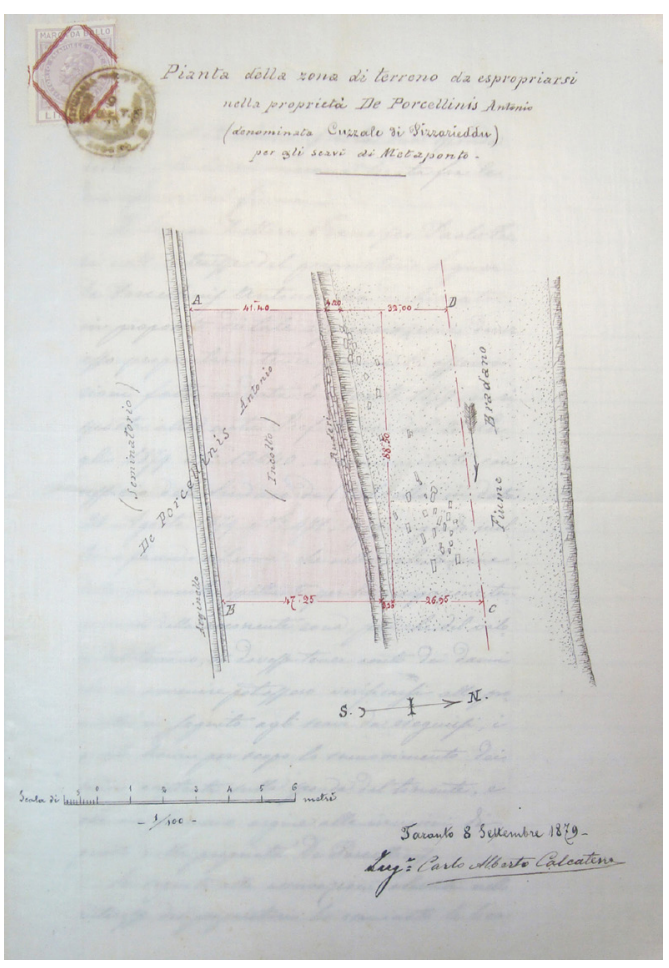


Fig. I I. Planimetric Sketch of the area known as "Colonne Paladine" for the expropriation of site for public benefit. The drawing reports the royal path that connected path that connected its deviation Puglia [ASPZ 1898-1902, b. 23, fasc. 31 ]

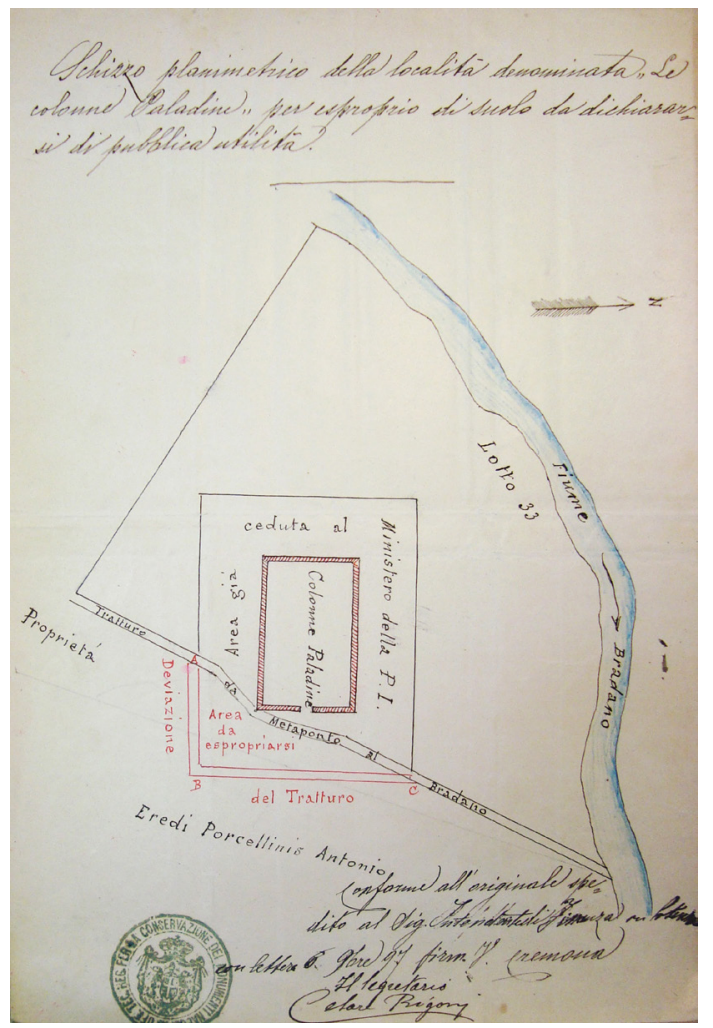

In 1877 he started new archeological investigations and two years later a motion for allowance to one year occupation was presented to Antonio de Porcellinis the owner of a land located in Cuzzale di Pizzarieddu, in Torre di Mare quarter, in the farmland of Pisticci. The request was made "with the aim to carry out excavations and in particular to discover pieces of column and architraves on the bank of the Bradano and in its bed belonging to a sumptuous temple and now covered by the river's silt" [4].

The task to define the expropriation allowance was entrusted to a state engineer of the Calabrian- Sicilian Railways, Carlo Alberto Calcaterra from Taranto who after opportune measurements he started drawing the area.

It consists of two papers, the first where the property of Mr. De Porcellinis are located on a larger scale and a second one where the area interested by archeological excavations is underlined by red color on a more detailed scale.

Few years later, in 1895 , a new hypothesis to better preserve the temple of Hera was to determine a buffer zone along each side of the monument, already protected by a fencing wall.

It is essential to proceed with the expropriation of a portion of land belonging to De Porcellinis's heirs, next to the east side and to the south-east corner of the temple [5]. Moreover studies had been conducted to identify the royal path leading from Calabria to Puglia and in particular, the track which linked Basento river to Bradano. Part of this track ran through the buffer zone identified as safeguard area for the ancient monument and so its deviation was proposed along the perimeter of this zone. That is what emerges from illustrative maps attached to the documents [6].

These documents, even if in small numbers, show a first feeling for graphic representation in the wider documental contest of archeological heritage of Basilicata often only demanded to written texts.

Tables, maps for technical survey and life drawings document an archeological heritage in a region not yet well known as Basilicata between the end of the XVIII and XIX century. 
Fig. 12. Survey drawing of 'Colonne Paladine' area from November 1898 [ASPZ I 898-1902, b. 23, fasc. 3I]

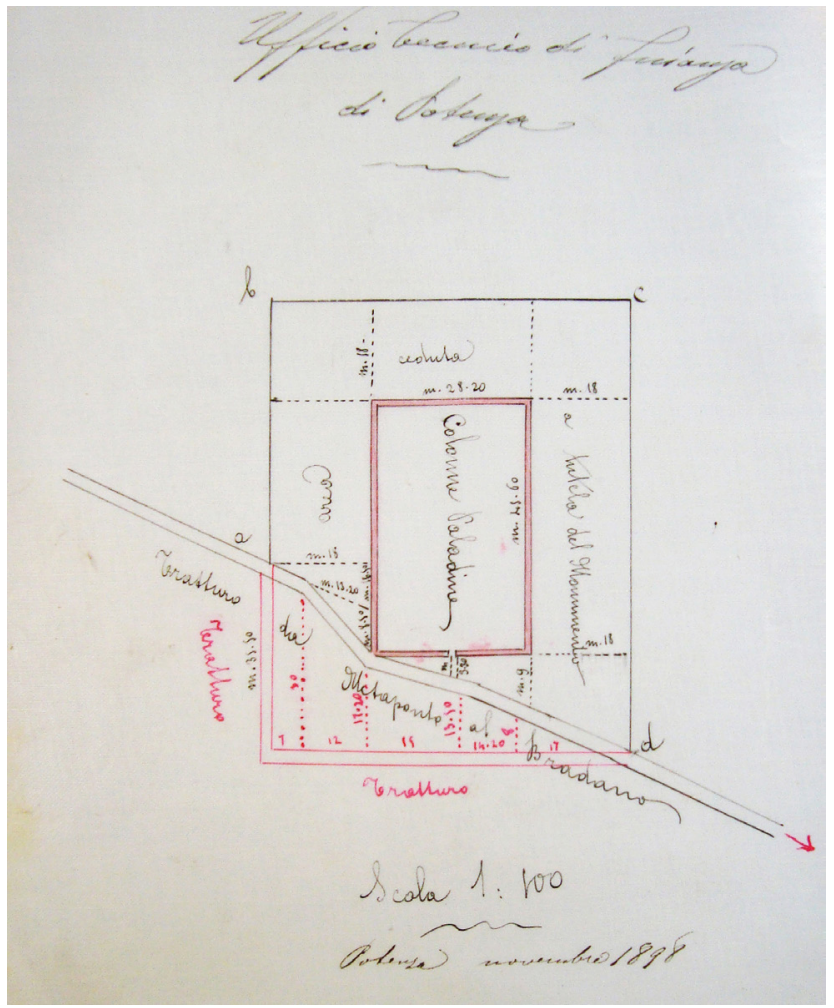

Archeological landscapes across narration and documentation: final notes

The study of documental sources even if chronologically uneven and incomplete and the in depth analysis about archeological documentation of Basilicata by 19th century literature allow to trace the new interest of 19th century intellectuals for archeological remains to be documented and handed down to posterity following a more "romantic" vision on the archeology of the time.

An inter-disciplinary approach to correctly interpret documents permits to define the archeological history in Basilicata and also to document, through a detailed analysis of graphic evidences, the changes of "archeological landscape" and the role that 19th century scholars had illustrating their results about ancient architecture and its use of color in their drawings and descriptive reports.

This study wants to represent a new tile in a larger debate about these graphic evidences adding other proofs concerning different and lesser-known geographical contexts, it allows us to deeply understand the knowledge of archeological territory of the XIX century through the drawing.

\section{Notes}

[I] For a complete picture of documentation concerning the archeological research in Basilicata stored at the State Archive of Potenza, see:Verrastro 1997.

[2] State Archive of Potenza, now known as ASPZ, Intendenza di Basilicata, b. (envelope) I337, fasc. (dossier) 7.

[3] In the XIXThe temple ruins of Apollo Licio were still visible, known as 'church of Sampson' by popular tradition from the biblical episode in which Sampson destroyed the temple of Philistine burying himself by its ruins. This building of Metaponto was told by the duke De Luynes: "its accumulated scraps marked the fast and complete ruin, the Bradano's flooding covered most of them under a significant layer of silt, from which columns and big Doric capitals come out completely unrecognizable. On the top of the soil there are many remains of moldings, Greek frets and lion heads" [Lacava I89I]. 
[4] ASPZ, Prefettura di Basilicata, Atti amministrativi (I 883-1887), b. 80, fasc. 609, memorandum for the requirement of the allowance for expropriation on September 8, 1879.

[5] ASPZ, Prefettura di Basilicata, Atti amministrativi (1898-1902), b. 23, fasc. 31, letter to the prefect of Basilicata from the architect of technical office of finance on October 8, I897; letter to the prefect of Basilicata on June I8, I898.

[6] ASPZ, Prefettura di Basilicata, Atti amministrativi (1898-1902), b. 23, fasc. 31 , letter to the Prefect of Basilicata on December 17,1898 .

\section{References}

Cardone Vito (2014). Viaggiatori d'architettura in Italia. Da Brunelleschi a Charles Garnier. Salerno: Università degli Studi - libreriauniversitaria.it.

Carpeggiani Paolo, Patetta Luciano (a cura di). (1989). Il disegno di architettura. Milano: Edizioni Angelo Guerini e associati.

Caserta Giovanni (a cura di). (2005). Viaggiatori stranieri in terra di Lucania Basilicata. Venosa: Osanna Edizioni.

Corti Siro ( I 889). Le province d'Italia sotto l'aspetto geografico e storico, Provincia di Potenza. Torino: G. B. Paravia.

Cundari Cesare et al. (2012). L'espressione grafica integrata per la documentazione e la conoscenza del patrimonio culturale. In Gráfica del diseño: tradición e innovaciones. Atti del IV congreso international de Expresión Gráfica en ingeniería, arquitectura y carreras afines. 17- 19 ottobre 2012 Universidad Nacional De La Plata. La Plata: GMG, pp. 367-37I.

De Rubertis Roberto (1992). Ermeneusi. In de Rubertis Roberto, Soletti Adriana, Ugo Vittorio. Temi e codici del disegno d'architettura. Roma: Officina Edizioni, pp. 179-226.

Guidano Guido ( 199 I). Intorno all'architettura. In Guidano Guido, Cerotto Paolo, Conte Antonio, Tolla Enza. Disegno, teoria e applicazioni. Potenza: Edizioni Ermes, pp. 9-20.

Lacava Michele ( 89 |). Topografia e storia di Metaponto. Napoli: Morano.

Ludovico Antonio (199I). Rilevamento architettonico e topografico metodi e strumenti nei secoli XVIII e XIX. I catasti geometrici preunitari e la misura generale del Granducato di Toscana. Roma: Edizioni Kappa.

Principe llario (|99|). Atlante storico della Basilicata. Cavallino (Lecce): Capone.

Sassu Rita (2019). Metaponto: II Tempio B del santuario urbano. In Giulierini Paolo, Giacco Marialucia (a cura di). Museo Archeologico Nazionale di Napoli. La collezione Magra Grecia. Milano: Electa, pp. I76- 179

Settembrino Giuseppe ( 1996). Archeologia e natura della costa ionica lucana. Il viaggio e l'evento. Venosa: Appia 2 editrice.

Tolla Enza, Bixio Antonio (20I2). Un laboratorio per il rilievo. Fisciano-Salerno: Edizioni CUES.

Verrastro Valeria (1997). Fonti per la storia dell'archeologia in Basilicata nell'Archivio di Stato di Potenza. In Bollettino Storico della Basilicata, n. 13, pp. I59-196.Venosa: Edizioni Osanna.

\section{Author}

Giuseppe Damone, Università degli Studi della Basilicata, giuseppe.damone@unibas.it

To cite this chapter. Damone Giuseppe (2020). Disegnare la memoria. I primi rilievi archeologici ottocenteschi in Basilicata/Edit the memory. The first archeological surveys in Basilicata of the XIXth Century. In Arena A., Arena M., Brandolino R.G., Colistra D., Ginex G., Mediati D., Nucifora S., Raffa P. (a cura di). Connettere. Un disegno per annodare e tessere. Atti del $42^{\circ}$ Convegno Internazionale dei Docenti delle Discipline della Rappresentazione/Connecting. Drawing for weaving relationships. Proceedings of the 42th International Conference of Representation Disciplines Teachers. Milano: FrancoAngeli, pp. 3203-3224. 